\title{
Competition and bank profitability
}

Nuraini Yuanita* ${ }^{*}$

${ }^{*}$ Correspondence: nyuanita@ojk.go.id Indonesia Financial Services Authority, Jl. MH Thamrin No. 2, Jakarta 10350, Indonesia

\begin{abstract}
By issuing Indonesian Banking Architecture in 2004, the central bank of Indonesia has encouraged banking sector to consolidate. The aim of merger among others is to increase bank economies of scale. This study tries to look at the impact of merger bank on the bank performance by implementing structure conduct and performance hypothesis. Merger bank affects market structure. According to structure conduct and performance hypothesis, market structure affects bank behavior as well as bank performance. The result of this study suggests that an increase in market concentration causes a decrease in price. It shows that merger increase economies of scale so that bank can offer lower price. A decrease in price brings down bank profitability. Concentration ratio also can be used as competition measurement. It is known as a structural measure of competition. Using the structural measure, a lower competition that is shown by higher concentration ratio is associated with lower profitability. This research also analyses the relationship between competition and bank profitability using Lerner index as a non-structural measure of competition. The non-structural measure of competition shows that lower competition is associated with higher profitability. Hence, the structural measure of competition creates different result from the non-structural measure of competition.
\end{abstract}

Keywords: Competition, Banking profitability, Lerner index, Ownership dispersion

JEL Classification: L1, D400, G210

\section{Introduction}

In 2004, Bank Indonesia as the banking supervisory authority encouraged banks to conduct consolidation. As one of the tools to encourage small banks to merge, Bank Indonesia issued Regulation No. 8/17/PBI/2006 regarding the Incentive for Banking Consolidation. Under the regulation, a bank that conducts consolidation through mergers and acquisitions will receive several benefits. On the other hand, as a pull factor Bank Indonesia also increased the minimum tier one capital that was mentioned in Bank Indonesia Regulation No. 7/15/PBI/2005. By conducting consolidation policies, it is expected that the banking sector will have a smaller bank number with a bigger size. Likewise, the number of players is one of the components of a market structure that shapes competition (Adhamovna 2016).

Nevertheless, the performance of the banking industry plays a significant role. Banking industry is a major financial source in Indonesia economy. By the end of December 2015, the total asset of the banking industry is more than 6.000 trillion Rupiahs while market capitalization in the capital market is around 5.000 trillion Rupiahs. In that regards, the

(c) The Author(s) 2019. This article is distributed under the terms of the Creative Commons Attribution 4.0 International License (http://creativecommons.org/licenses/by/4.0/), which permits unrestricted use, distribution, and reproduction in any medium, provided you give appropriate credit to the original author(s) and the source, provide a link to the Creative Commons license, and indicate if changes were made. 
performance of the banking sector is important to be analyzed. Banking performance can be measured in many ways. Banking profitability is one measurement of banking performance. Profitability is important for the bank to survive and grow.

This research tries to find a relationship between competition and profitability by employing both structural and non-structural approach. In a structural approach, the structure conduct and performance hypothesis are applied while for non-structural hypothesis, this study uses Lerner index as a competition measurement.

Even though there are some limitations in our study, to our knowledge, the present study extends the empirical literature in some respects. Regarding competition analysis, this research analyses both structural and non-structural approaches. Since 2012, banks in Indonesia are classified into four groups based on their size. In this research, analysis for each bank group is done to identify whether any differences exist among bank groups. Moreover, this research employs a quadratic function of competition in the regression equation. A consolidation process will affect not only the bank but also the ownership structure of the bank. This study enriches the literature by analyzing ownership structure using the Herfindahl-Hirschman Index (HHI index).

\section{Literature review}

Oxford dictionary explains "competition is the activity or condition of striving to gain or win something by defeating or establishing superiority over others." Cambridge dictionary explains that "competition is a situation in which someone is trying to win something or be more successful than someone else." Cambridge and Oxford dictionary explain competition as situation and condition; in that regard, many aspects can describe a condition and situation. Hence, there is some aspect that can be used to measure competition as a description of situation or condition. The literature on competition divide competition measurement into two main streams. The first group called structural approach that uses information on a structural characteristic of the market. Some example of structural information is market shares, number of firms, the barrier to entry, and concentration of the market. On the other side, there is a non-structural measurement that does not use any information on the market structure rather directly measure the competition itself. Some example of non-structural approach is the Lerner index, $\mathrm{H}$ statistic or Panzar-Rosse method (H-Statistic) and Bresnahan Model.

The main structural market measurement for the competition is the concentration ratio. Concentration ratio is the most widely used indicator of the structural approach. Under the structural measure, concentration ratio impacts bank performance. The basic theory for the relation is structured conduct and performance hypothesis.

The traditional Structure Conduct and Performance (SCP) suggest that there may be a collusive behavior if the market is dominated by a few big firms. The higher the market concentration, the higher their profit as a result of collusive behavior. The SCP hypothesis suggests that there is a positive relationship between market concentration and profit. Moreover, Mishra and Sahoo (2012) proved that the relationship between structure, conduct and performance is not necessarily unidirectional.

The SCP hypothesis has been challenged by Efficiency (structural) Hypothesis (ES or ESH). According to ESH, the positive direction of performance and concentration is the result of firm efficiency. Firm efficiency will produce higher profit and will gain 
more market share. SCP hypothesis mentioned that concentration is matter while ESH hypothesis believes that market share is more important as a parameter of market structure as posited by Molyneux \& Forbes (1995). Tests between SCP and ESH hypothesis are captured by the equation:

$$
\pi_{i}=\beta_{0}+\beta_{1} C R+\beta_{3} M S+\sum_{i=1}^{m} \alpha_{i} X_{i}
$$

where $\pi$ is profitability, CR is concentration ratio, MS is market shares and $X$ is control variables.

ESH hypothesis is supported when MS coefficient is significant, and the SCP hypothesis is supported when CR coefficient is significant.

Some researchers tried to prove which hypothesis is supported using single-country data as well as multiple countries data. Researchers that support SCP hypothesis among others are Lloyd-Williams et al. (1994) who use Spanish data. The result supports the traditional SCP paradigm as an explanation for the market behavior of Spanish banks. In Malaysia, Katib (2004) employs a panel of 20 domestic commercial banks for the years 1989-1996 in the Malaysian banking industry. The result shows that market structure determines the profitability of the Malaysian banking industry suggesting SCP hypothesis is held in Malaysia banking sector. In Pakistan banking industry, Bhatti \& Hussain (2010) utilize data of Pakistani commercial banking market over the period 1996-2004. The result rejects the efficiency hypothesis. Lü and Liu (2012) found that the coefficient of market structure is significant in comparison to market shares; they found a negative relationship between oligopoly degree and bank performance. Moreover, Nabieu (2013) using 19 Ghana commercial bank data found significant coefficient for both market structure variable as well as market shares variable suggesting a support to SCP hypothesis. Using Vietnamese banking data from 2005 to 2012 Hien and Hanh (2014) support the SCP hypothesis.

On the other hand, there are also some researchers that support Efficiency hypothesis. Smirlock (1985) mentioned that there is a non-relationship between market structure and profitability. The relation exists between market shares and profitability. The SCP hypothesis has also been evaluated by Evanoff and Fortier (1988) that can prove the ES hypothesis. In their study, Evanoff and Fortier (1988) mentioned some important factor in conducting SCP hypothesis, among other are entry barriers variable, "proper" market structure measure, inclusive and current data, simultaneous analysis of SCP and ES hypothesis. Moreover, Samad (2008) who examine SCP and ESH hypothesis in Bangladesh banking industry utilize data of 44 commercial banks operating in Bangladesh. The research conducts 12 equations and among those equations two equations are significant and support efficiency hypothesis. In Sri Lanka banking sector, Seelanatha (2010) found that bank performance depends on efficiency while market structure and market power are not significant variables to bank performance. Sahile et al. (2015), using data of 44 commercial banks in Kenya from 2000 to 2009 found that efficient bank maximizes profitability. Moreover, Khan and Jan (2014) use multi-country data set shows that in Southeast Asia banking, before the 1997 financial crisis, the traditional SCP hypotheses are not held. 
With regard to profit-structure relationship in Indonesia's banking industry, Silalahi et al. (2015) who utilize quarterly data of 98 commercial banks from 2005-2014 have investigated the relationship between concentration ratio and market share to the performance of banks and shows that in Indonesia banking sector the SCP hypothesis is held.

Lerner index is one of non-structural approaches in measuring competition. Lerner index is the most commonly used indicator for explaining competition (Adhamovna 2016) and is also the most widely cited index (Elzinga and Mills 2011). The Lerner index was initiated by Abba Lerner's 1934 paper in the Review of Economic Studies (Elzinga and Mills 2011). The study tried to measure social loss from monopolies by taking the gap between price and marginal cost. For Lerner, the bigger the gap, the higher the degree of monopoly. Despite its limitations, the Lerner index is the bestknown measure of monopoly power (Elzinga and Mills 2011).

With regards to the competition-performance relationship, Athoammar and Muharam (2015) investigated the relationship of competition with bank efficiency and found that competition has a negative effect on bank efficiency. The research utilizes Lerner index as a competition parameter while efficiency is calculated by the stochastic frontier approach.

\section{Data and methodology}

This research uses 93 banks in the sample with data set from 2000 to 2015. The data are taken from Indonesia Financial Services Authority.

The SCP hypothesis stated that market structure determines market behavior and market behavior will determine performance. This research uses a concentration ratio that consists of Concentration Ratio of the biggest four banks (CR4) and HHI as the measurement of market structure. For the behavior, this research chooses price as an indicator, because the price competition is one of conduct in analyzing the banking industry (Neuberger 1998). As banking is a profit-seeking entity, this study uses profitability as the performance of the banking sector. Return on Assets is employed to measure bank profitability. Price in this analysis is estimated using a ratio between total revenue to total loans. Figure 1 shows the analytical framework in employing the SCP Hypothesis.

As the price is rigid, this research will include the lag of the dependent variable into the equation that shows relation between market structure and price. To avoid bias estimation, this paper employs the Arellano Bond GMM system into the equation to treat the lag of the dependent variable. Equation 1 that measures the relationship between market structure and market behavior is:

$$
\text { PRICE }_{i t}=\alpha+\alpha_{2} \text { PRICE }_{i t-1}+\delta_{1} \text { Market Structure }_{t}+\delta_{2} \text { Market Structure }_{t}^{2}+\varepsilon_{i t}
$$

PRICE is calculated by dividing total revenue by total loan; market structure is concentration ratio measured by $\mathrm{HHI}$ and CR4. High concentration ratio shows low competition. Theoretically, the market structure will have a positive relationship with price. In a highly concentrated market, firms have a higher market power to set a price above their marginal cost (Jansen and de Haan 2003). However, the empirical 


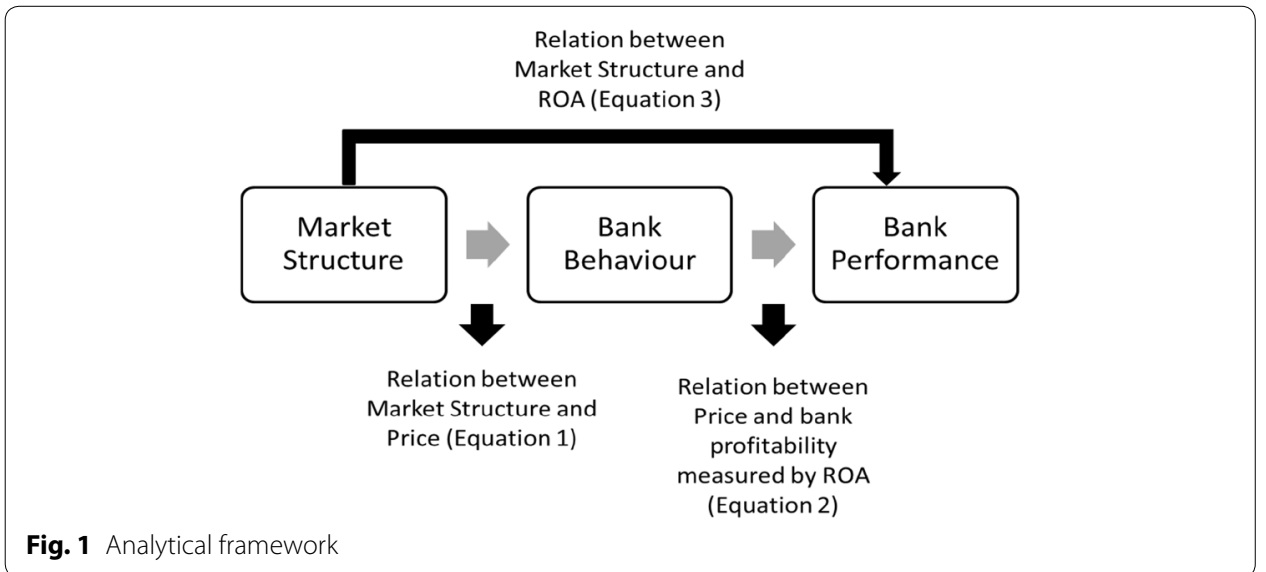

study that finds the relationship between market structure and behavior is rare (Bikker and Haaf 2002).

Equation 2 that is used to find the relationship between price and bank profitability is:

$$
\begin{aligned}
\mathrm{ROA}_{i t}= & \alpha+\delta_{1} \text { Price }_{i t}+\delta_{2} C_{i t}+\delta_{3} \mathrm{NPL}_{i t}+\delta_{4} \mathrm{Eqta}_{i t} \\
& +\delta_{5} \text { HHIownership }_{i t}+\delta_{6} \mathrm{DBClass}_{t}+\varepsilon_{i t}
\end{aligned}
$$

ROA is a return on assets, $\mathrm{CI}$ is a cost-to-income ratio, NPL is a non-performing loan, Eqta is equity-to-assets ratio, and HHIownership is ownership concentration. DBClass is a dummy for the period of bank classification.

The cost-to-income ratio explains inefficiency in the bank. A more efficient bank will have higher profitability. Hence, this study expects a negative relationship between the cost-to-income ratio and profitability. Jansen and de Haan (2003) also conduct research where efficiency is one of the variables in profitability to check the efficiency hypothesis.

A non-performing loan is included in the equation to explain credit risk in the bank. The higher the non-performing loan, the higher the risk. When a bank has a big portion of non-performing loan, it means those bad loan proportions do not produce profit like a healthy loan, rather NPL creates expense to the bank. Hence, this study expects a negative relationship between NPL and profitability. Some researchers also consider risk in the profit determinant equation such as Athanasoglou et al. (2008) who use loan loss provision-to-loan ratio.

Equity-to-assets ratio shows a proportion of equity in comparison to total assets. As an intermediary agent, the bank collects fund from people while the equity is only a certain proportion to the total assets managed by the bank. Equity will be a buffer for the bank when there is a fluctuation in profitability. Equity-to-assets ratio can have a positive or negative relationship with bank profitability. A bank that has a relatively big portion of equity is a prudent bank; hence they have good risk management and have high profitability. However, high equity-to-assets ratio also creates a cost to the bank and will reduce bank profit. Hence there is no expected sign for the equity-toassets ratio. Athanasoglou et al. (2008) found a positive relationship between equityto-assets ratio and profitability in the Greek banking sector. 
This paper includes ownership structure into the equation as the consolidation policy will impact not only the concentration of the banking sector but also the concentration of ownership in a bank. When merger, consolidation, and acquisition happened, the composition of the owners may be changed. This research uses information of ownership structure in the equation. Highly concentrated ownership means that the bank is owned by a small number of owners with a high percentage of shares ownership, while a low value of concentration ratio shows that the bank is owned by a large number of the owners with small shares of ownership. The ownership concentration is calculated using the HHI Index by replacing market shares with ownership shares. There is no expected sign for ownership concentration. A positive coefficient means a bank that is owned by concentrated owner tends to be more profitable. High profitability shows that the controlling owner has the opportunity to supervise management and owners tend to perform the supervisory function correctly. A negative coefficient suggests that the controlling owner tends to use the bank for their interest and tends to abuse bank interest, so that reducing bank profitability.

Since 2012, commercial banks in Indonesia are classified into four groups. This research uses dummy 1 for the period after classification. The classification is important as the size of the banks is used to determine bank business activities. After 2012, the smaller bank can only conduct limited business activities while the biggest bank group can have a full license in the banking business. We expect that the classification will reduce bank profitability as it creates more restriction on the banks.

When Eq. 1 is inserted into Eq. 2, we get Eq. 3 as shown below to find the relationship between market structure and bank profitability.

$$
\begin{aligned}
\text { ROA }_{i t}= & \alpha+\delta_{1 a} \text { Market Structure }_{t}+\delta_{1 b} \text { Market Structure }_{t}^{2} \\
& +\delta_{2} \mathrm{CI}_{i t}+\delta_{3} \mathrm{NPL}_{i t}+\delta_{4} \mathrm{Eqta}_{i t} \\
& +\delta_{5} \text { HHIownership }_{i t}+\delta_{6} \text { DBClass }_{t}+\varepsilon_{i t}
\end{aligned}
$$

The positive relationship between market structure and profitability is expected. A concentrated market gives market power to firms so that they can set the price above their marginal cost and create higher profitability. However, some researchers find a negative relationship as well as a non-significant result. Some studies claim that market structure usually has a negative relationship with profitability once other effects are controlled in the equation (Athanasoglou et al. 2008). In this regard, there is no expectation for the concentration ratio. Moreover, the coefficient of concentration ratio and the square of concentration ratio are expected to have opposite signs. In this situation, the relationship between concentration ratio with profitability will be either a $U$ curve or an inverted U curve.

As this research employs both structural and non-structural approach, Eq. 3 is used to find the relation between competition and profitability. By changing the market structure variable into Lerner index, this study finds competition-profitability relationship using non-structural approach. Lerner index explains the gap between product prices and the marginal cost of production in terms of percentage of price. The data and method to calculate Lerner index follow Yuanita (2019). Method to calculate Lerner index is shown in illustration 1. 
Table 1 Data summary. Source: Author's calculation on data provided by the Indonesia Financial Services Authority

\begin{tabular}{lrrrlr}
\hline Variable & Obs & \multicolumn{1}{c}{ Mean } & Std. dev. & \multicolumn{1}{c}{ Min } & \multicolumn{1}{c}{ Max } \\
\hline ROA & 1365 & 2.361 & 3.025 & -15.820 & 57.000 \\
CR4 & 1395 & 0.470 & 0.022 & 0.445 & 0.523 \\
HHI & 1395 & 687.119 & 73.985 & 626.244 & 858.042 \\
PRICE & 1377 & 0.117 & 0.061 & 0 & 2.019 \\
Cl & 1374 & 81.062 & 21.797 & 20.335 & 461.811 \\
NPL & 1347 & 2.125 & 3.125 & 0.000 & 44.000 \\
HHI ownership & 1288 & 5020.186 & 2891.730 & 0.000 & $10,000.000$ \\
Eqta & 1364 & 0.144 & 0.103 & 0.013 & 0.990 \\
\hline
\end{tabular}

Table 2 Correlation matrix. Source: Author's calculation on data provided by the Indonesia Financial Services Authority

\begin{tabular}{lcccccccc}
\hline & ROA & CR $_{\mathbf{4}}$ & HHI & PRICE & Cl & NPL & HHIOwner & EQTA \\
\hline ROA & 1 & & & & & & & \\
CR & 0.0945 & 1 & & & & & & \\
HHI & 0.1069 & 0.9668 & 1 & & & & & \\
PRICE & 0.2153 & 0.1354 & 0.1805 & 1 & & & \\
Cl & -0.7864 & -0.0949 & -0.1 & -0.0247 & 1 & & \\
NPL & -0.1668 & 0.2116 & 0.2447 & 0.0974 & 0.0755 & 1 & \\
HHIOwner & -0.0826 & -0.0277 & -0.0386 & -0.1332 & -0.0027 & 0.0197 & 1 & \\
EQTA & 0.0695 & -0.095 & -0.1235 & -0.1496 & -0.0478 & -0.1184 & 0.2086 & 1 \\
\hline
\end{tabular}

Table 3 Granger causality test for SCP hypothesis. Source: Author's calculation on data provided by the Indonesia Financial Services Authority

\begin{tabular}{lll}
\hline & $\boldsymbol{Z}$ bar tilde & $\boldsymbol{P}$ value \\
\hline HHI cause PRICE & 6.1043 & $0.0000^{*}$ \\
$\mathrm{CR}_{4}$ cause PRICE & 4.8877 & $0.0000^{*}$ \\
PRICE cause ROA & 1.5901 & 0.1118 \\
$\mathrm{HHI}$ cause ROA & 1.1182 & 0.2635 \\
$\mathrm{CR}_{4}$ cause ROA & 0.9116 & 0.3620 \\
\hline
\end{tabular}

* A significant result at $99 \%$ confidence interval

\section{Result and findings}

Tables 1 and 2 show the summary statistics and correlation matrix for data used in this analysis. Data used in the calculation have been trimmed by deleting some extreme values that are not logical such as the negative values of price and NPL that are over 100.

Before conducting a regression analysis, this study conducted a Granger Causality Test to know whether the relationship has a causal relationship. The result of the Granger causality test is shown in Table 3.

The Granger causality test shows that only two sets of variables have causal relationships, the relationship between CR4 and price as well as the relationship between HHI and price. In this regard, change in market structure causes change in price. 
Table 4 Regression result for market structure-price relation. Source: Author's calculation on data provided by the Indonesia Financial Services Authority

\begin{tabular}{|c|c|c|c|c|c|c|}
\hline \multirow{2}{*}{$\begin{array}{l}\text { Dependent variable: PRICE } \\
\text { Independent variables: }\end{array}$} & \multicolumn{3}{|l|}{$\mathrm{CR}_{4}$} & \multicolumn{3}{|l|}{$\mathrm{HHI}$} \\
\hline & Coef & $T$ stat & $P$ value & Coef & $T$ stat & $P$ value \\
\hline L. PRICE & 0.510 & 12.41 & 0.000 & 0.56357990 & 13.21 & 0.000 \\
\hline Market structure & -7.91 & -5.57 & 0.000 & -0.0006208 & -2.71 & 0.008 \\
\hline Market structure 2 & 8.056 & 5.43 & 0.000 & 0.00000039 & 2.49 & 0.015 \\
\hline \multicolumn{3}{|l|}{ Arellano-bond test for AR(1) } & 0.000 & & & 0.000 \\
\hline \multicolumn{3}{|l|}{ Arellano-bond test for AR(2) } & 0.608 & & & 0.722 \\
\hline \multicolumn{3}{|c|}{ Hansen test of over-identification restrictions } & 0.409 & & & 0.408 \\
\hline \multicolumn{3}{|l|}{ Inflexion point } & 0.491 & & & 779.899 \\
\hline \multicolumn{3}{|l|}{ Number of observation } & 1166 & & & 1166 \\
\hline \multicolumn{3}{|l|}{ Number of sample } & 93 & & & 93 \\
\hline
\end{tabular}

\subsection{Relationship between market structure and price}

The results of the relationship between market structure and price are shown in Table 4 . Both regression results using $\mathrm{HHI}$ and CR4 as the parameter of the market structure show a consistent result. The lag of the dependent variable is highly significant and has a positive relationship with price. The coefficient in the lag of the dependent variable shows the speed of adjustment.

The regression result for the relationship between market structure and price is contrary to the theory. The result shows that the more concentrated the market, the lower the price. The argument behind the result is that a merger can increase economies of scale. Merger will increase concentration ratio; on the other hand merger will increase economies of scale of merged bank. In term of size, merged bank is getting bigger. The bigger bank will have a better scale of the economy so that they can offer a better price. A merger is one of the ways to increase size. In this regard, the merger process will increase the concentration ratio but also will increase the scale of the economy of the bank so that they can provide a lower price.

As expected, the market structure and square of market structure have the opposite sign. In Indonesia's commercial banking sector, market structure has a negative coefficient while the square of market structure has a positive sign. The result shows that the relationship between market structure and price forms a $\mathrm{U}$ curve.

\subsection{Relationship between price and profitability}

In conducting the regression between price and profitability, this study employs random effect. Random effect was chosen because of the fact that profitability is affected by many other random variables that are not explained by an individual bank. Table 5 shows the regression result.

The regression result shows that price has a positive relationship with profitability as expected. The higher the price, the higher the profitability. The cost-to-income ratio shows a negative and significant sign. The negative relationship explains that an effective bank has high profitability. Non-performing loan ratio shows a significant and negative sign; the result shows that a bank that has high non-performing loan will have lower 
Table 5 Regression result for price-profitability relation. Source: Author's calculation on data provided by the Indonesia Financial Services Authority

\begin{tabular}{llcc}
\hline Dependent var: ROA & Coef & $\boldsymbol{T}$ stat & $\boldsymbol{P}$ value \\
\hline PRICE & 10.345 & 4.71 & 0.000 \\
Cl & -0.049 & -2.77 & 0.006 \\
NPL & -0.061 & -4.14 & 0.000 \\
HHlownership & -0.00003 & 0.0000203 & 0.135 \\
Eqta & 3.286 & 2.70 & 0.007 \\
DBClass & -0.405 & -3.01 & 0.003 \\
Constant & 4.947 & 3.59 & 0.001 \\
R Sq & 0.506 & & \\
Number of observation & 1234 & & \\
Number of sample & 93 & & \\
Adj R sq & 0.503 & & \\
\hline
\end{tabular}

Clustering is applied in the random effect regression to deal with heteroskedasticity and autocorrelation

Table 6 Regression result for the relationship between market structure and profitability. Source: Author's calculation on data provided by the Indonesia Financial Services Authority

\begin{tabular}{|c|c|c|c|c|c|c|}
\hline \multirow{2}{*}{$\begin{array}{l}\text { Dependent var: } \\
\text { ROA }\end{array}$} & \multicolumn{3}{|l|}{$\mathrm{HHI}$} & \multicolumn{3}{|l|}{ CR4 } \\
\hline & Coef & $T$ stat & $P$ value & Coef & $T$ stat & $P$ value \\
\hline \multicolumn{7}{|l|}{ Independent variables } \\
\hline $\mathrm{Cl}$ & -0.482 & -2.81 & 0.005 & -0.0482 & -2.8 & 0.005 \\
\hline NPL & -0.065 & -4.53 & 0.000 & -0.0664 & -4.67 & 0.000 \\
\hline HHlownership & $-4.00 E-05$ & -1.82 & 0.068 & $-3.81 \mathrm{E}-04$ & -1.73 & 0.084 \\
\hline Eqta & 3.159 & 2.48 & 0.013 & 3.2019 & 2.52 & 0.012 \\
\hline DBClass & -0.368 & -3.91 & 0.001 & -0.447426 & -3.76 & 0.000 \\
\hline constant & 1.927 & 0.22 & 0.827 & 79.3036 & 3.18 & 0.001 \\
\hline Market structure & 0.009 & 0.45 & 0.653 & -309.1588 & -3.11 & 0.002 \\
\hline Market structure 2 & $-4.50 E-06$ & -0.33 & 0.741 & 325.9586 & 3.18 & 0.001 \\
\hline $\mathrm{R} \mathrm{Sq}$ & \multicolumn{3}{|l|}{0.4763} & \multicolumn{3}{|l|}{0.4735} \\
\hline Number of observations & \multicolumn{3}{|l|}{1234} & \multicolumn{3}{|l|}{1234} \\
\hline Number of samples & \multicolumn{3}{|l|}{93} & \multicolumn{3}{|l|}{93} \\
\hline
\end{tabular}

Clustering is applied in the random effect regression to deal with heteroskedasticity and autocorrelation

profitability as expected. The equity-to-assets ratio shows a positive result. A bank that has a high equity proportion can earn more profit due to good risk management. High equity-to-assets ratio also shows prudent behavior.

\subsection{Relationship between market structure and profitability}

Before conducting the regression, this study conducted a modified Wald test and Wooldridge test to check heteroscedasticity and autocorrelation both for regression with CR4 as well as HHI. This study found that both regressions contain heteroscedasticity as well as autocorrelation. This study also conducts a Hausman test to choose between fixed effects and random effects. The result shows that for both 
regressions, random effect is more appropriate. Table 6 shows the regression result for the relationship between market structure and profitability with random effects.

The results for regression with $\mathrm{HHI}$ and CR4 do not go in the same direction. While CR4 shows a significant factor in profitability, HHI is not a significant variable to explain profitability. CR4 shows a negative and significant relationship while HHI becomes a positive and non-significant factor for profitability.

Regression result using CR4 shows that the relationship between market structure and profitability is contrary to the theory; the higher the CR4, the lower the profitability is. Higher CR4 means the four biggest banks have acquired a higher market share. The higher the CR4 mean values, the higher the domination of the biggest four banks in the market. To increase dominance, the biggest four banks need to perform expansion. Market expansion creates expenses to the bank, and some of the expansion does not create profit during the particular year. For example, the bank that introduces a new product or expands to a new area has high expenses, but the profitability is still relatively low. In this regard, an increase in market shares of the four bigger banks is followed by a decrease in ROA. Moreover, bigger banks tend to have a better economy of scale. By having a higher economy of scale, a bank can have a lower marginal cost. By having a lower marginal cost, the bank has an option to reduce its price to gain more market shares. A decline in price can reduce bank profitability in term of percentage.

The regression results with $\mathrm{HHI}$ as a parameter of market structure did not show a significant coefficient. This result suggests that HHI is not a significant factor in bank profitability. HHI movement is affected by all banks' market shares. An increase in small bank shares will increase HHI. An increase in HHI is caused by many factors, among others are the merger that occurred in BUKU 1, 2, and 3. A successful merger can increase efficiency and increase profitability. However, some mergers need longer time to show performance while the cost of merger deteriorates ROA. Based on the above results, the relationship between market structure and return on assets can be deepened by looking at the regression for each bank classification. Banks in the same group tend to be more homogenous so that conducting regression for each group hopefully can give a clearer picture.

This study conducted the same process as in the previous regression and also checked the Blue assumption. Moreover, this study conducted Hausman test to determine between fixed effect and random effect. Table 7 shows the regression result for each BUKU when CR4 is used as the measurement of market structure.

The result shows that CR4 and HHI are significant factors for BUKU 1 and 3. An increase in concentration ratio is associated with lower profitability. An increase in $\mathrm{CR} 4$ and $\mathrm{HHI}$ can be because of the merger process. The negative relationship can be a result of the bank's effort to expand its market share by conducting some activities that reduce their profitability such as increased number of branched and outlets. The negative relationship also can be a result of a merger, consolidation, and acquisition. When merger consolidation and acquisition occur, concentration increase at the same time and the merged bank spends more budget so that profitability decreases. Table 8 shows the regression result between HHI and profitability for each BUKU. 
Table 7 Regression result for CR4 and profitability relationship for each BUKU. Source: Author's calculation on data provided by the Indonesia Financial Services Authority

\begin{tabular}{|c|c|c|c|c|c|c|c|c|}
\hline \multirow{2}{*}{$\begin{array}{l}\text { Dependent } \\
\text { var: } \\
\text { ROA }\end{array}$} & \multicolumn{2}{|l|}{ BUKU 1} & \multicolumn{2}{|l|}{ BUKU 2} & \multicolumn{2}{|l|}{ BUKU 3} & \multicolumn{2}{|l|}{ BUKU 4} \\
\hline & Coef & $P$ value & Coef & $P$ value & Coef & $P$ value & Coef & $P$ value \\
\hline \multicolumn{9}{|c|}{ Independent variable } \\
\hline $\mathrm{Cl}$ & -0.108 & 0.000 & -0.032 & 0.073 & -0.045 & 0.000 & -0.013416 & 0.078 \\
\hline NPL & -0.047 & 0.013 & -0.074 & 0.000 & -0.106 & 0.000 & -0.0755782 & 0.348 \\
\hline HHlownership & $-3.63 E-05$ & 0.175 & $-2.10 \mathrm{E}-05$ & 0.635 & $-7.90 \mathrm{E}-05$ & 0.006 & $-2.20 E-04$ & 0.002 \\
\hline Eqta & 0.989 & 0.268 & 4.870 & 0.161 & 7.878 & 0.002 & 1.208707 & 0.838 \\
\hline DBClass & -0.176 & 0.124 & -0.821 & 0.0000 & -0.443 & 0.000 & 0.3588605 & 0.257 \\
\hline Constant & 107.176 & 0.000 & 50.006 & 0.34 & 87.534 & 0.020 & 24.28634 & 0.426 \\
\hline CR4 & -401.440 & 0.000 & -194.200 & 0.368 & -342.180 & 0.028 & -83.79603 & 0.527 \\
\hline CR42 & 418.481 & 0.000 & 207.148 & 0.357 & 358.257 & 0.027 & 91.17098 & 0.529 \\
\hline $\mathrm{RSq}$ & 0.754 & & 0.423 & & 0.532 & & 0.5297 & \\
\hline $\begin{array}{l}\text { Number of } \\
\text { observations }\end{array}$ & 580 & & 312 & & 286 & & 56 & \\
\hline $\begin{array}{c}\text { Number of } \\
\text { samples }\end{array}$ & 43 & & 25 & & 22 & & 4 & \\
\hline
\end{tabular}

BUKU is bank classification based on Indonesia Financial Services Authority regulation. BUKU 1 is the smallest bank group that has limited bank business activities, and BUKU 4 is the biggest bank group that has full banking business license

The non-significant result of regression in BUKU 2 and BUKU 4 can be caused by the number of mergers in the group. During the observation period, there is no merger occurring in BUKU 4. The non-significancy also can be caused by different result and accounting treatment during merger process that can affect bank profitability. There are several banks in BUKU 2 which conducted merger during the observation period. Some of the mergers cause a reduction in their ROA but some did not show a decline in the ROA.

Table 8 Regression result for $\mathrm{HHI}$ and profitability relationship for each BUKU. Source: Author's calculation on data provided by the Indonesia Financial Services Authority

\begin{tabular}{|c|c|c|c|c|c|c|c|c|}
\hline \multirow{2}{*}{$\begin{array}{l}\text { Dependent var: } \\
\text { ROA }\end{array}$} & \multicolumn{2}{|l|}{ BUKU 1} & \multicolumn{2}{|l|}{ BUKU 2} & \multicolumn{2}{|l|}{ BUKU 3} & \multicolumn{2}{|l|}{ BUKU 4} \\
\hline & Coef & $P$ value & Coef & $P$ value & Coef & $P$ value & Coef & $P$ value \\
\hline \multicolumn{9}{|l|}{ Independent var } \\
\hline $\mathrm{Cl}$ & -0.108 & 0.000 & -0.032 & 0.073 & -0.048 & 0.000 & -0.013 & 0.098 \\
\hline$N P L$ & -0.045 & 0.009 & -0.080 & 0.000 & -0.098 & 0.001 & -0.083 & 0.331 \\
\hline HHlownership & $-3.79 E-05$ & 0.151 & $2.30 \mathrm{E}-05$ & 0.588 & 0.000 & 0.004 & $-2.16 \mathrm{E}-04$ & 0.002 \\
\hline Eqta & 0.880 & 0.317 & 4.630 & 0.196 & 8.085 & 0.003 & 1.844 & 0.733 \\
\hline DBClass & -0.129 & 0.269 & -0.706 & 0.002 & -0.373 & 0.002 & 0.366 & 0.254 \\
\hline constant & 23.281 & 0.001 & -13.509 & 0.321 & 5.062 & 0.568 & -0.398 & 0.876 \\
\hline $\mathrm{HHI}$ & -0.035 & 0.060 & 0.047 & 0.183 & 0.001 & 0.977 & 0.013 & 0.079 \\
\hline $\mathrm{HHI} 2$ & $-2.97 E-05$ & 0.047 & $-2.97 E-06$ & 0.214 & $-8.47 \mathrm{E}-07$ & 0.957 & $-7.26 \mathrm{E}-06$ & 0.091 \\
\hline $\mathrm{RSq}$ & 0.750 & & 0.425 & & 0.523 & & 0.535 & \\
\hline $\begin{array}{l}\text { No of observa- } \\
\text { tion }\end{array}$ & 580 & & 312 & & 286 & & 56 & \\
\hline $\begin{array}{c}\text { Number of } \\
\text { sample }\end{array}$ & 43 & & 25 & & 22 & & 4 & \\
\hline
\end{tabular}

BUKU is bank classification based on Indonesia Financial Services Authority regulation. BUKU 1 is the smallest bank group that has limited bank business activities, and BUKU 4 is the biggest bank group that has full banking business license 


\subsection{Relationship between Lerner index and profitability}

To compare the structural and non-structural result, this study uses Lerner index the measurement of competition. The data set and method to calculate Lerner index were from Yuanita (2019). Formulas to calculate Lerner index are shown in Appendix 1. The regression between the Lerner index and profitability in this section uses the same data set that was used to analyzed market concentration and profitability.

The regression results in Table 9 show that the Lerner index has a positive relationship with bank performance. The higher the Lerner index, the higher the ROA. As a high Lerner index shows low competition, the regression result shows that lower competition is associated with higher profitability. This result is opposite to the market structureprofitability regression that shows a negative relationship between market structure and profitability. A high value of market structure shows that the market is concentrated, and hence has low competition. In the case of a market structure-profitability relationship, low competition is associated with low profitability. The opposite result of both regressions shows that the way the researcher defines the competition affects the result of the regression. Hence, a different type of competition measurement can be used based on the purpose of analysis. Among different types of measurement of competition, it would not always create a consistent result as a different way of looking at the competition. The concentration ratio such as CR4 and HHI explains the concentration of the market that sometimes does not always explain competition as measured by Lerner index. Even when the number of firms is great; the competition can be low such as when each player has their owned market niche so that they can have sufficient margin. When the number of players decreases, the competition in the market does not always decline.

The market structure-profitability and market power-profitability relationship can explain different phenomena. The market structure explains the impact of bank size to profitability while market power gives more explanation at the level of competition in the market.

The $\mathrm{U}$ curve relationship cannot be proved in the Lerner-profitability relationship, suggesting that Lerner index has a linear relationship to profitability. Lerner index

Table 9 Regression result for Lerner index and profitably relationship. Source: Author's calculation on data provided by the Indonesia Financial Services Authority

\begin{tabular}{llrr}
\hline $\begin{array}{l}\text { Dependent variable } \\
\text { ROA }\end{array}$ & Coef & $\boldsymbol{T}$ stat & $\boldsymbol{P}$ value \\
Independent variables & & & \\
\hline $\mathrm{Cl}$ & & & -0.097 \\
$\mathrm{NPL}$ & -0.065 & -3.97 & -0.062 \\
HHlownership & -0.034 & -2.37 & 0.013 \\
Eqta & $-5.04 \mathrm{E}-05$ & -2.49 & 0.330 \\
DBClass & -0.908 & -0.97 & 0.084 \\
Constant & -0.159 & -1.73 & 0.000 \\
Lerner & 6.225 & 3.63 & 0.018 \\
Lerner 2 & 4.656 & 2.38 & 0.800 \\
R Sq & -0.606 & -0.25 & \\
No of observation & 0.608 & & \\
No of sample & 991 & & \\
\hline
\end{tabular}


measures competition through margin between price and marginal cost. The margin also explains bank profitability so that Lerner index will have a linear relationship with profitability.

The concentration of ownership shows a negative and significant result. It is shown that a bank that is owned by concentrated owners has lower profitability in comparison to a bank that is owned by the less-concentrated owner. In concentrated ownership, the majority owner can have additional information and can conduct a supervisory role in the bank. The owner can use its supervisory function in the bank to pursue its interest and undermine bank interests. From policy implications, a bank with highly concentrated ownership needs to be supplemented with some governance structure and processes such as better transparency, and an obligation to have a more independent director and commissioner.

\section{Conclusion and policy recommendation}

From the above research findings, this study proposes some policy recommendations such as support to continue the consolidation policy in Indonesia banking sector, monitoring different measurement of competition and disperse the ownership structure.

The consolidation policy conducted by the authority is supported by most of the findings of this study. This study finds that an increase in market concentration causes a decrease in price. By conducting a merger, the bank will be bigger in terms of asset and bank can achieve higher economies of scale so that the bank can have a lower marginal cost. By having a lower marginal cost bank can provide lower price for customer. The increase of economy of scale can be seen in BUKU 3 and BUKU 1 .

This study finds that a structural measure of competition produces a different result from the non-structural measure of competition. It suggests that each of the measurements explains a different side of competition. Hence, monitoring several measures of competition can give a better explanation of competition in the Indonesia banking sector.

The single presence policy has been implemented in Indonesia. The policy requires bank owners who own more than one bank to consolidate their banks. By implementing this policy, there is a tendency for an increase in ownership concentration. This study finds that concentrated ownership is associated with lower profitability. In this situation, when the single presence policy needs to be implemented, a better governance needs to be supplemented.

Acknowledgements

The author acknowledges the funding support from Indonesia Financial Services Authority through a scholarship to take a Ph.D. degree in Nagoya University. This study is part of author dissertation as a fulfilment of the degree.

\section{Authors' contributions}

Even though there are some limitations in our study, to our knowledge, the present study extends the empirical literature in: conducting both structural and non-structural analysis, analyzing each bank group, employing a quadratic function in SCP hypothesis and adding the dispersion ownership variable. The author read and approved the final manuscript.

\section{Funding}

This study is part of author's dissertation when taking Ph.D. program in Nagoya University. During the study, the author received scholarship from the Indonesia Financial Services Authority.

Availability of data and materials

This research utilizes publicly available data. Data for individual bank are taken from Indonesia Financial Services Authority. 


\section{Appendix 1}

Illustration 1

\section{Lerner index calculation}

Lerner index explains the gap between product prices and the marginal cost of production in terms of percentage of price. The standard formula of the Lerner index is the difference between price and marginal cost divided by price.

Price can be calculated by computing the ratio of the total revenue to the total output. Marginal cost can be determined by employing a trans-log cost function. The homogenous price index is used in this equation so that the price of the input is normalized by one of the input prices. In this research the formula for trans-log cost function is:

$$
\begin{aligned}
\operatorname{Ln} \mathrm{TC}= & \alpha_{0}+\alpha_{1} \operatorname{Ln} y+\frac{1}{2} \alpha_{2}(\ln y)^{2}+\sum_{j=1}^{3} \beta_{j} \ln w_{j}+\sum_{j=1}^{3} \frac{1}{2} \beta_{j} \ln w_{j}^{2} \\
& +\sum_{j=1}^{3} \sum_{k=1}^{3} \beta_{j k} \ln w_{j} \ln w_{k}+\sum_{j=1}^{3} \gamma_{j} \ln y \ln w_{j} \\
& +\sum_{j=1}^{3} \rho_{j} \text { trend } \ln w_{j}+\mu_{0}(\operatorname{Ln} y * \text { trend })+\mu_{1} \text { tren }+\frac{1}{2} \mu_{2} \text { trend }^{2}+\varepsilon
\end{aligned}
$$

where TC is total cost, $\mathrm{y}$ is the total loan, W1 is the price of labor (the ratio of personnel cost to the total assets), W2 is the price of physical capital (the ratio of all other costs excluding interest, personnel, and impairment costs to the total assets), W3 is the price of borrowed funds (the ratio of interest cost-to-third-party funds). W4 is the price of capital charged for assets deterioration (the ratio of impairment costs to the total assets). Total cost and input price are normalized by W4 to have a homogenous price standard.

The trans-log cost function is computed using Generalized Least Square. The regression result is used to calculate marginal costs by employing the first derivative of the cost function with respect to total loan as shown below:

$$
\mathrm{MC}=\frac{\mathrm{TC}}{y}\left(\alpha_{1}+\alpha_{2} \ln y+\sum_{j=1}^{3} \gamma_{j} \ln w_{j}+\mu_{0} \text { trend }\right)
$$

Received: 22 May 2019 Revised: 16 August 2019 Accepted: 3 September 2019

Published online: 13 September 2019

References

Adhamovna BG (2016) Banking competition and stability: comprehensive literature review. Int J Manag Sci Busin Admin 2(6):26-33

Athanasoglou PP, Brissimis SN, Delis MD (2008) Bank-specific, industry-specific and macroeconomic determinants of bank profitability. J Int Finan Mark Inst Money 18(2):121-136. https://doi.org/10.1016/j.intfin.2006.07.001

Athoammar NH, Muharam H (2015) Analisis pengaruh kompetisi, size, capitalization, dan loans Intensity terhadap efisiensi perbankan (studi kasus perbankan umum konvensional di Indonesia periode tahun 2008-2012). Fakultas Ekonomika dan Bisnis. http://eprints.undip.ac.id/46523/

Bhatti GA, Hussain H (2010) Evidence on structure conduct performance hypothesis in Pakistani commercial banks. Int J Bus Manag 5(9):174

Bikker JA, Haaf K (2002) Competition, concentration and their relationship: an empirical analysis of the banking industry. J Bank Finance 26(11):2191-2214

Elzinga KG, Mills DE (2011) The Lerner index of monopoly power: origins and uses. Am Econ Rev 101(3):558-564 
Evanoff DD, Fortier DL (1988) Reevaluation of the structure-conduct-performance paradigm in banking. J Finan Serv Res 1(3):277-294

Hien PT, Hanh PM (2014) Analysis of factors affecting performance of Vietnamese commercial banks: testing SCP and ES hypotheses. J Econ Dev 219:81-92

Jansen DJ, de Haan J (2003) Increasing concentration in European Banking: a macro-level analysis. SSRN Electron J. https ://doi.org/10.2139/ssin.518422

Katib MN (2004) Market structure and performance in the Malaysian Banking Industry: a robust estimation. In 8th

Capital Markets Conference, Indian Institute of Capital Markets Paper, http://papers.ssrn.com/sol3/papers.cfm?abstr act_id $=872266$

Khan SJ, Jan S (2014) Concentration in Southeast Asia Banking. Am J Econ 4(3):150-158

Lloyd-Williams DM, Molyneux P, Thornton J (1994) Market structure and performance in Spanish Banking. J Bank Finance 18(3):433-443

Lü Z, Liu Q (2012) China Banking market structure and performance: based on panel data 2000-2010. Int Busi Manag $5(2): 146-151$

Mishra P, Sahoo D (2012) Structure, conduct and performance of Indian Banking Sector. Rev Econ Perspect 12(4):235-264 Nabieu GA (2013) The Structure, conduct and performance of commercial bank in Ghana. Eur J Busi Innov Res 1(4):34-47 Neuberger D (1998) Industrial organization of banking: a review. Int J Econ Busi 5(1):97-118. https://doi. org/10.1080/13571519884594

Sahile G, Solomon W, Tarus DK, Cheruiyot TK (2015) market structure-performance hypothesis in Kenyan banking industry. Int J Emerg Mark 10(4):697-710

Samad A (2008) Market structure, conduct and performance: evidence from the Bangladesh Banking Industry. J Asian Econ 19(2):181-193

Seelanatha L (2010) Market structure, efficiency and performance of banking industry in Sri Lanka. Banks Bank Syst 5(1):20-31

Silalahi T, Manurung A, Hidayat Y (2015) The Market structure of the bank, its performance and the macroprudential policy. Buletin Ekonomi Moneter Dan Perbankan 18(1):45-60. https://doi.org/10.21098/bemp.v18i1.514

Smirlock M (1985) Evidence on the (non) relationship between concentration and profitability in banking. J Money Credit Bank 17(1):69-83

Yuanita N (2019) Does competition Diminish Indonesia's banking stability. Forum Int Dev Stud 49-3:1-16

\section{Publisher's Note}

Springer Nature remains neutral with regard to jurisdictional claims in published maps and institutional affiliations.

\section{Submit your manuscript to a SpringerOpen ${ }^{\circ}$ journal and benefit from:}

- Convenient online submission

- Rigorous peer review

- Open access: articles freely available online

- High visibility within the field

- Retaining the copyright to your article

Submit your next manuscript at $\gg$ springeropen.com 